\title{
The Use of Horse Radish Peroxidase, an Eco-Friendly Method for Removal of Phenol from Industrial Effluent
}

\author{
Dr. Suneeti Gore ${ }^{1}$, Dr. Arika Kotha ${ }^{2}$, Dhanashree Nevgi ${ }^{3}$ Juhi Shah ${ }^{4}$ \\ 1.Department of Microbiology, Fergusson College, Pune. \\ 2.MIT College of Engineering, Alandi, Pune \\ 3,4. Past post graduate student of Department of Microbiology \\ Email id of corresponding author: suneetigore@gmail.com
}

\begin{abstract}
The rising population, increasing urbanization, rapid industrialization and spread of more water intensive life styles are making water resources scarce and polluted. waste waters of various industries such as textile, petroleum, refining, plastics etc. contain phenolic compounds. (1) Due to toxicity of these compounds to aquatic organisms and humans, it is necessary that phenolic compounds are removed from contaminated water before they are discharged into any natural stream of water. In this study, the removal of phenolic contaminants was undertaken biologically by using peroxidase enzyme. This enzyme was extracted from various natural sources like carrot, radish, broccoli, beetroot, soybean as well as some microorganisms like Pseudomonas aeruginosa NCIM 2200, Bacillus subtilis and Staphylococcus aureus NCIM 2079. Peroxidases catalyse the oxidation of phenols by hydrogen peroxide which results in the formation of water insoluble polymers which can be separated by coagulation, sedimentation etc. The prime objective of this work was to develop an eco-friendly, economical and effective biological method of removing phenolic pollutants from the waste water. The most effective peroxidase enzyme was white radish peroxidase which showed maximum enzyme activity. It exhibited above $90 \%$ phenol removal potential. This compound could be tested further by making certain formulations.
\end{abstract}

Key words: Hydrogen peroxide, peroxidase, Phenol, polymers

\section{Introduction}

Water pollution is a major global problem. It is the leading worldwide cause of deaths and diseases and it accounts for the deaths of more than 3 million people annually (WHO world water day report). Water is typically referred to as polluted when it is impaired by anthropogenic contaminants and either does not support a human use, such as drinking_water, and/or undergoes a marked shift in its ability to support its constituent biotic communities, such as fish. Waste water from manufacturing or chemical processes in industries contributes to water pollution. Industrial waste water usually contains specific and readily identifiable chemical compounds. Industrial activities should comply with the regulatory norms for prevention and control of water pollution. Rapid industrialisation is having an adverse effect on our environment resulting in the generation of industrial effluents. Due to high organic load and toxic materials, industrial effluents form a major source of water pollution. High concentration of metallic effluents such as, Cadmium, Zinc, Mercury, Manganese, Iron and others generating from the untreated effluents get accumulated in the food chain and thereby affect the human health when the food is consumed. These contaminants can interfere with the formation of red blood cells that may show harmful effects in humans. Presence of phenolic compounds even at low concentrations in the industrial waste water adversely affects aquatic as well as human life directly or indirectly when disposed off to public sewage, river or surface water. Phenolic contaminants are observed in wastewaters of various industries like photo developing chemicals, petroleum refining, coal conversion, textiles, iron and steel manufacturing, plastics, as well as pulp and paper manufacturing. Various phenolic derivatives like 2,4-dichlorophenol, xylenol, cresol, bisphenol form a major part of the phenolic contaminants in industrial effluents (2). The phenol concentrations in these wastewaters range from 1.0 to $10.0 \mathrm{mM} \mathrm{(100} \mathrm{to} 1000 \mathrm{mg} / \mathrm{L})$. Phenols of anthropogenic origin may enter the environment because of uncontrolled discharges or accidental spills. It may also accumulate as an intermediate during incomplete biodegradation of aromatic compounds and pesticide mixtures. Peroxidases (EC number 1.11.1.x) are a large family of enzymes that typically catalyse a reaction of the form (3)

$$
\text { ROOR' + electron donor }\left(2 \mathrm{e}^{-}\right)+2 \mathrm{H}^{+} \square \mathrm{ROH}+\mathrm{R}^{\prime} \mathrm{OH}
$$

Peroxidase also catalyse the phenol removal. (4)

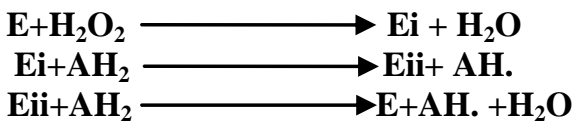


The native enzyme (E) gets oxidized by hydrogen peroxide $\left(\mathrm{H}_{2} \mathrm{O}_{2}\right)$ to an active intermediate enzymatic form called compound I (Ei). Compound I then accept an aromatic compound $\left(\mathrm{AH}_{2}\right)$ into its active site and carries out its oxidation. A free radical $\left(\mathrm{AH}^{\circ}\right)$ is then produced and it is released into solution leaving the enzyme in the compound II (Eii) state.

Compound II further oxidizes a second aromatic molecule, releasing another free radical product and returning the enzyme to its native state, thereby completing the cycle. The overall peroxidase reaction consists of the reactions described by the above Equations. Free radicals formed during the cycle diffuse from the enzyme into the bulk solution where they react to form poly aromatic products. The water-insoluble polymers may be removed by solid liquid operations. Phenol is the most potent industrial pollutant being carcinogenic and genotoxic. MWPCB [Maharashtra Water Pollution Control Board] has norms for discharge of phenol in natural water bodies [1 ppm] Phenol is toxic to fish at a level of $0.05 \mathrm{mg} / \mathrm{lit}$. WHO has set a limit of $0.1 \mathrm{mg} / \mathrm{ml}$ to regulate the level of phenol in drinking water. The standard processes for phenol removal from industrial wastewaters include extraction, bacterial and chemical oxidation, adsorption on activated carbon, irradiation, electrochemical techniques, etc. These methods have several shortcomings such as high costs, incompleteness of purification, hazardous by-products formation, low efficiency and could be applied to a limited range of concentration. There are certain advantages of using enzyme technique. Over conventional phenol removal system. They are Cost effective. Broad substrate specificity. High reaction rates, Milder reaction condition, No hazardous end products. And it shows activity over a wide range of $\mathrm{pH}$, temperature end salinity ranges.

\section{Materials And Methods}

\section{Extraction of enzyme peroxidase from natural sources and microorganisms}

The natural sources like radish, broccoli, carrot, soybean and beetroot were used for the extraction of peroxidase. These vegetables were washed, cleaned and crushed. The juice was filtered and $60 \%$ ammonium sulphate was added in the juice. The centrifugation was carried out at $4000 \mathrm{rpm}$ for $20 \mathrm{~min}$ at $4{ }^{0} \mathrm{C}$. The supernatant was taken and the enzyme peroxidase was extracted using the $90 \%$ Ammonium sulphate precipitation. (5)

\section{Biodegradation of phenol (6)}

The micro-organisms used Pseudomonas aeruginosa, Staphylococcus aureus and Bacillus subtilis were assessed to study their potential of biodegradation of phenol. In this assay the ability of the organisms to utilise phenol as a sole carbon source was evaluated. The phenol degrading activity of all the bacterial strains was evaluated. The micro-organisms were grown on a mineral salt agar medium which was supplemented with phenol concentration of $200 \mathrm{mg} / 1$ at $25^{\circ} \mathrm{C}$ for $72 \mathrm{hrs}$.

The composition of mineral salt agar medium in $\mathrm{g} / \mathrm{l}$ was: $\mathrm{KH}_{2} \mathrm{PO}_{4}-0.42, \mathrm{~K}_{2} \mathrm{HPO}_{4}-0.375,\left(\mathrm{NH}_{4}\right){ }_{2} \mathrm{SO}_{4}-0.244$, $\mathrm{NaCl}-0.015, \mathrm{CaCl}_{2} \cdot 2 \mathrm{H}_{2} \mathrm{O}-0.015, \mathrm{MgSO}_{4} .7 \mathrm{H}_{2} \mathrm{O}-0.05, \mathrm{FeCl}_{3} \cdot 6 \mathrm{H}_{2} \mathrm{O}-0.054$. The significance of the study was the assessment of the above bacteria for their potential of bioremediation.

\section{Measurement of peroxidase activity (7)}

The principle of the test is: In the peroxidase assay Guaiacol is used as the substrate.

$$
\text { Guaiacol }+\mathrm{H}_{2} \mathrm{O}_{2} \longrightarrow \text { Oxidized Guaiacol }+2 \mathrm{H}_{2} \mathrm{O}
$$

The oxidized (dehydrogenated) Guaiacol that is formed is probably more than one compound and its formation depends on the reaction conditions. The rate of formation of Guaiacol dehydrogenation product is a measure of the peroxidase activity and can be assayed spectrophotometrically at $436 \mathrm{~nm}$. The chemicals and reagents used in this test were, Phosphate buffer $0.1 \mathrm{M}(\mathrm{pH} 7)$, Guaiacol solution $20 \mathrm{Mm}$, Hydrogen peroxide solution $(0.042 \%=12.3 \mathrm{Mm})$, Enzyme extract. $3 \mathrm{ml}$ buffer solution, $0.05 \mathrm{ml}$ Guaiacol solution, $0.1 \mathrm{ml}$ enzyme extract and $0.03 \mathrm{ml}$ hydrogen peroxide solution was pipetted out in a cuvette. The resulting mixture of the reactants was assayed spectrophotometrically. The absorbance could increase by 0.05 . A stop watch was used to note the time required in minutes $(\Delta t)$ to increase the absorbance by 0.1 . The reaction rate is determined by measuring an increase in absorbance resulting from the decomposition of hydrogen peroxide. One unit results when the decomposition of one micromole of hydrogen peroxide takes place per minute at $25^{0} \mathrm{C}$ and $\mathrm{pH} 7.0$ under specified condition.

As the extinction coefficient of Guaiacol dehydrogenation product at $436 \mathrm{~nm}$ under the conditions specified is 6.39 per micromole, the enzyme activity per litre of extract could be calculated as follows:

Enzyme activity units/litre $=3.18 \times 0.1 \times 1000 / 6.39 \times \Delta t \times 0.1$
$=500 / \Delta t$ 


\section{Phenol removal assay ( 8 )}

The phenol removal assay is a phenol concentration measurement assay. From this assay the ability of each of the extracted peroxidase enzymes to remove phenol is evaluated. A reduction in the concentration of phenol is directly correlated to the efficiency of the extracted peroxidase enzymes from the natural sources and microorganisms. Their efficiency to polymerise and thereby to remove phenol can be assessed from this assay. Phenol concentration is measured by a colour reaction based on the condensation of 4-AAP [4AminoAntiPyrine] with phenol in the presence of alkaline oxidising reagents like potassium ferrocyanide $\left[\mathrm{K}_{3} \mathrm{FeCn}_{6}\right]$. This results in the formation of antipyrine dyes. The formation of antipyrine dyes is a measure of phenol concentration which is assayed colorimetrically at $510 \mathrm{~nm}$. The chemicals and reagents used in this test were $20.8 \mathrm{mM}$ 4-Aminoantipyrine, 2. $0.25 \mathrm{M}$ sodium bicarbonate, $83.4 \mathrm{mM}$ potassium ferrocyanide, Phenol solution. The assay mixture contains $2 \mathrm{ml}$ of phenol, $2 \mathrm{ml}$ enzyme solution, $4 \mathrm{ml}$ of $0.25 \mathrm{M}$ sodium bicarbonate and $0.9 \mathrm{ml} 20.8 \mathrm{mM}$ 4-AAP. After proper mixing $0.9 \mathrm{ml}$ of $83.4 \mathrm{mM}$ potassium ferrocyanide is added and vigorously mixed. The absorbance of the samples was measured at $510 \mathrm{~nm}, 9$ min after the Ferro cyanide addition and converted to concentration using calibration curve. The above phenol removal assay was performed using:1] Synthetic phenol.2] Industrial effluent. The initial concentration of phenol in industrial effluent was measured using the above assay extracted peroxidase enzyme. Synthetic phenol and industrial effluent were reacted with the extracted peroxidase enzyme at different time intervals. A reduction in the phenol concentration was correlated to phenol removal potential of the enzyme.

\section{Optimization of $\mathrm{pH}$ and temperature}

The term "immobilization" refers to the trapping of biomolecules or whole living cells. Immobilized enzymes are defined as "enzymes physically confined or localized in a certain defined region of space with retention of their catalytic activities, and which can be used repeatedly and continuously." Every enzyme exhibits maximum activity at a specific $\mathrm{pH}$ and temperature value. This value is known as the optimum $\mathrm{pH}$ and temperature of the enzyme of the most effective peroxidase enzyme was optimised by measuring the activity of enzyme at $\mathrm{pH} 3,5,7$ and 9 . The temperature of the most effective peroxidase enzyme was optimised by measuring the activity of enzyme at $25^{\circ} \mathrm{C}, 37^{\circ} \mathrm{C}$ and at $55^{\circ} \mathrm{C}$. The enzyme activity of the enzyme was evaluated using the following assay: The chemicals and reagents used were Phosphate buffer $0.1 \mathrm{M}(\mathrm{pH} 3,5,7,9)$ Guaiacol solution $20 \mathrm{Mm}$ Hydrogen peroxide solution $(0.042 \%=12.3 \mathrm{Mm})$ Enzyme extract. $3 \mathrm{ml}$ buffer solution, $0.05 \mathrm{ml}$ Guaiacol solution, $0.1 \mathrm{ml}$ enzyme extract and $0.03 \mathrm{ml}$ hydrogen peroxide solution was pipetted out in a cuvette. The resulting mixture was then placed in the spectrophotometer. The absorbance could increase by 0.05 . A stop watch was used to note the time required in minutes $(\Delta t)$ to increase the absorbance by 0.1 . The $\mathrm{pH}$ of the phosphate buffer used was varied in the assay $(\mathrm{pH} \mathrm{3,} 5,7,9)$ The assay mixture was exposed to temperatures of $25^{\circ} \mathrm{C}, 37^{\circ} \mathrm{C}$ and at $55^{\circ} \mathrm{C}$ for temperature optimisation.

\section{Immobilization of the enzyme peroxidase}

The term "immobilization" refers to the trapping of biomolecules or whole living cells. Immobilized enzymes are defined as "enzymes physically confined or localized in a certain defined region of space with retention of their catalytic activities, and which can be used repeatedly and continuously." For the immobilization of the extracted peroxidase enzyme the Entrapment method was used. The chemicals required were 5\%Sodium alginate solution, Enzyme solution, $5 \mathrm{ml}$ Syringe, $3 \%$ calcium chloride. The Enzyme solution was mixed with $5 \%$ aqueous Sodium alginate solution. The resulting mixture was slowly extruded as droplets through a $5 \mathrm{ml}$ syringe into chilled Calcium chloride solution. Calcium alginate Beads were stored at $4^{0} \mathrm{C}$ in buffer for further use.

\section{Lyophilisation of the enzyme peroxidase extracted from radish}

Freeze-drying also known as lyophillization or cryodesiccation is a dehydration process typically used to preserve a perishable material or make the material more convenient for transport. The enzyme peroxidase extracted from radish showed the maximum activity for phenol removal from industrial effluent. Hence the extracted peroxidase enzyme from radish was subjected to lyophilisation.

\section{Ammonium sulphate fractionation}

\section{Results}

The ammonium sulphate fractionation method was used for the extraction of enzyme peroxidase from various natural sources and microorganisms. The extracted enzyme mixture was stored at $4^{\circ} \mathrm{C}$ for further use.

\section{Biodegradation of phenol}

There was no growth seen on the mineral salt agar medium. The organisms could not use phenol as a sole carbon source. Therefore, the isolates used did not exhibit any biodegradation potential. 
The Use of Horse Radish Peroxidase, an Eco-Friendly Method for Removal of Phenol from ....

\subsection{Reduction of synthetic phenol}

Reduction of synthetic phenol over a time range of 1,2,24 and 48 hours was studied. The O.D. reading of $0.3 \mathrm{M}$ phenol solution at $510 \mathrm{~nm}$ was found to be 0.03 using UV-VIS spectrophotometer. Due to activity of various peroxidase containing enzyme extracts from natural sources and micro-organisms, there was removal of phenol which was correlated by reduction in absorbance.

Table 1: Reduction of synthetic phenol

\begin{tabular}{|l|l|l|l|l|l|}
\hline \multicolumn{1}{|c|}{ Natural sources } & \multicolumn{4}{c|}{ O.D at 510 nm } \\
\hline & & $\mathbf{1 ~ H o u r}$ & $\mathbf{2}$ Hrs & $\mathbf{2 4}$ Hrs \\
\hline 1. & Radish & 0.022 & 0.017 & 0.007 & 0.001 \\
\hline 2. & Broccoli & 0.026 & 0.020 & 0.010 & 0.003 \\
\hline 3. & Soybean & 0.025 & 0.018 & 0.008 & 0.009 \\
\hline 4. & Carrot & 0.024 & 0.019 & 0.006 & 0.006 \\
\hline 5. & Beetroot & 0.023 & 0.018 & & 0.005 \\
\hline & Micro-organisms & & & & 0.024 \\
\hline 1. & P. aeruginosa & 0.029 & 0.027 & 0.023 & 0.021 \\
\hline 2. & Staphylococcus aureus & 0.028 & 0.025 & 0.023 \\
\hline 3. & Bacillus subtilis & 0.026 & 0.024 & 0.023 \\
\hline
\end{tabular}

\section{Measurement of peroxidase activity}

The Guaiacol assay was used for measurement of the activity of the extracted peroxidase enzyme. The rate of formation of Guaiacol dehydrogenation product was a measure of the peroxidase activity and was assayed spectrophotometrically at $436 \mathrm{~nm}$. Since the extinction coefficient of Guaiacol dehydrogenation product at $436 \mathrm{~nm}$ under the conditions specified is 6.39 per micromole, the enzyme activity per litre of extract was calculated as below:

Enzyme activity units/litre $=3.18 \times 0.1 \times 1000 / 6.39 \times \Delta t \times 0.1$

$$
=\mathbf{5 0 0} / \Delta \mathbf{t}
$$

Table 2: Measurement of peroxidase activity

\begin{tabular}{|c|c|c|c|}
\hline Sr. No. & Natural sources & t (mins) & Enzyme activity in units/lit \\
\hline 1. & White Radish & 2 & 250 \\
\hline 2. & Red radish & 2.1 & 240 \\
\hline 3. & Broccoli & 2.5 & 200 \\
\hline 4. & Soybean & 2.7 & 185 \\
\hline 5. & Carrot & 3 & 166 \\
\hline 6. & Beetroot & 3.3 & 150 \\
\hline 1. & Micro-organisms & 50 \\
\hline 2. & Pseudomonas aeruginosa & \\
\hline 3. & Bacillus subtilis & 6.2 & 100 \\
\hline
\end{tabular}

\section{Removal of phenol (9)}

A phenol concentration measurement is done by the phenol removal assay. From this assay the ability of each of the extracted peroxidase enzymes to remove phenol was evaluated. A reduction in the concentration of phenol was directly correlated to the efficiency of the extracted peroxidase enzymes from the natural sources and microorganisms. Their efficiency to polymerise and thereby to remove phenol was assessed from this assay. The phenol concentration is measured by a colour reaction based on the condensation of 4-aap [4aminoantipyrine] with phenol in the presence of alkaline oxidising reagents like potassium ferrocyanide $\left[\mathrm{k}_{3} \mathrm{fecn}_{6}\right]$. this resulted in the formation of antipyrine dyes. The formation of antipyrine dyes was a measure of phenol concentration which was assayed colorimetrically at $510 \mathrm{~nm}$.

The samples used in the phenol removal assay were: 1] synthetic phenol 2] industrial effluent. Since the highest peroxidase activity was observed in the enzyme extract from white radish, peroxidase enzyme from white radish was incorporated in the phenol removal assay.

\subsection{Synthetic phenol}

1] A graph representing reduction in the concentration of synthetic phenol by enzyme peroxidase from white radish was drawn. The graph shows that with an increase in the enzyme dose, the removal of phenol increases. The initial phenol concentration was $4.5 \mathrm{mg} / \mathrm{l}$ and the final concentration reduced to $1.1 \mathrm{mg} / \mathrm{l}$. This shows that there was more than $90 \%$ removal of phenol. 


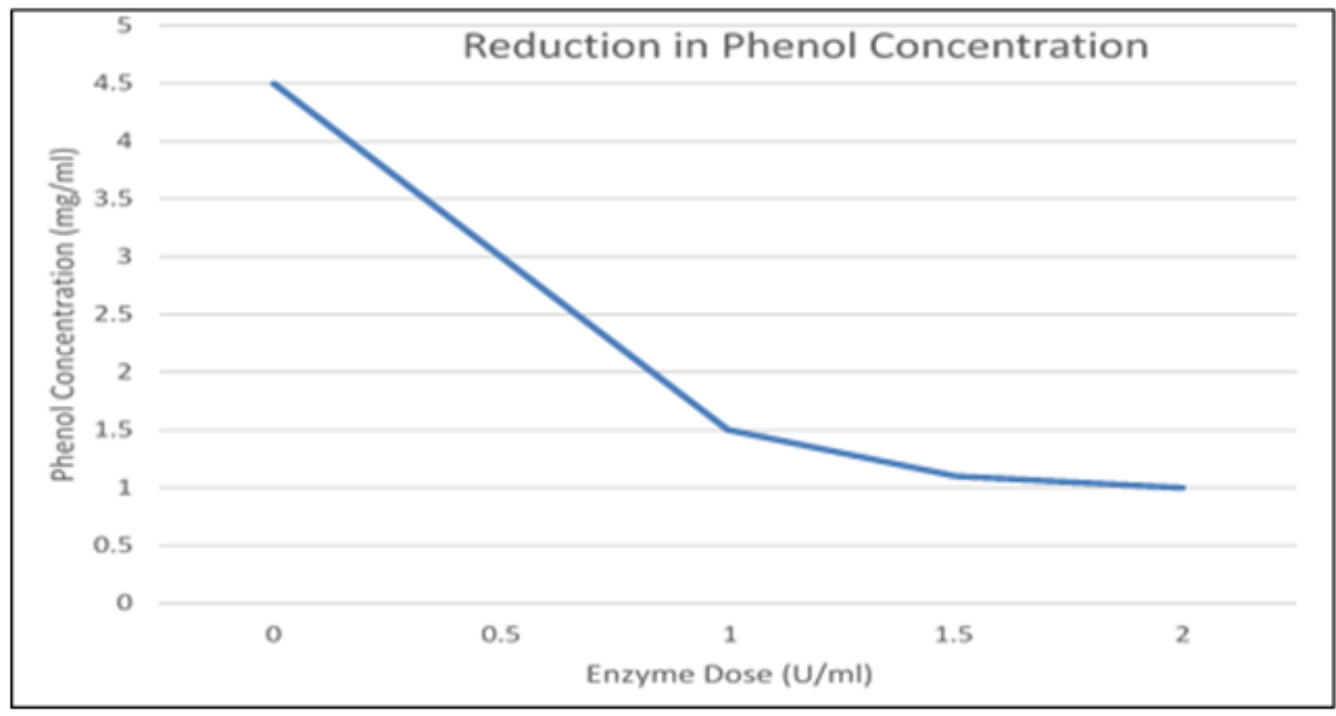

2] Synthetic phenol concentration ranging from $1 \mathrm{mM}$ to $10 \mathrm{mM}$ were prepared and tested for the reduction in the concentration of phenol after addition of white radish peroxidase. This synthetically prepared phenol was subjected to the phenol concentration measurement assay to measure the reduction in the phenol concentration.

Table 3: Removal of phenol

\begin{tabular}{|c|c|c|c|c|c|}
\hline \multirow{2}{*}{ Test } & \multicolumn{9}{|c|}{ Phenol Concentration } & \multirow{2}{*}{ Phenol Conversion (\%) } \\
\cline { 2 - 5 } & $\mathbf{3}$ Initial & $\mathbf{m g} / \mathbf{l}$ & $\mathbf{M m}$ & $\mathbf{m g} / \mathbf{l}$ & \\
\cline { 2 - 5 } & $\mathbf{m M}$ & 94 & 0.011 & 1.0 & 90 \\
\hline 1 & 1 & 188 & 0.003 & 0.3 & 99 \\
\hline 2 & 2 & 376 & 0.005 & 0.5 & 99 \\
\hline 3 & 4 & 564 & 0.002 & 0.2 & 99 \\
\hline 5 & 6 & 752 & 0.012 & 1.1 & 99 \\
\hline 6 & 8 & 940 & 0.009 & 0.9 & 99 \\
\hline
\end{tabular}

From the above result table, it was observed that in all experimental conditions phenol conversion was greater than $90 \%$. The high efficiency of phenol removal observed was in accordance with conditions optimized to guarantee $90 \%$ polymerisation of phenol using purified white radish peroxidase.

\subsection{Industrial effluent}

To evaluate the decrease in concentration of phenol, the initial concentration of phenol in the industrial effluent was determined using the phenol removal assay. The concentration of phenol in the industrial effluent was determined by measuring the absorbance at $510 \mathrm{~nm}$. This was performed to study the efficiency of the enzyme peroxidase from white radish to remove phenol from industrial effluent. The decrease in the phenol concentration at different time intervals was assessed.

Table 4: Concentration of phenol in industrial effluent.

\begin{tabular}{|c|c|}
\hline Industrial effluent & O.D. at 510 nm \\
\hline Phenol & 4.000 \\
\hline
\end{tabular}

Table 5: Decrease in the absorbance of phenol from industrial effluent

\begin{tabular}{|c|c|}
\hline Time(mins) & O.D at 510 nm \\
\hline 10 & 3.129 \\
\hline 20 & 0.230 \\
\hline 40 & 0.220 \\
\hline 60 & 0.137 \\
\hline
\end{tabular}

In about 20 mins, phenol conversion higher than $90 \%$ was observed by the polymerisation reaction.

\section{Optimization of $\mathrm{pH}$ and temperature}

Since maximum peroxidase activity and maximum phenol removal was shown by white radish enzyme extract optimisation of the $\mathrm{pH}$ and temperature of peroxidase from white radish extract was performed. 
The Use of Horse Radish Peroxidase, an Eco-Friendly Method for Removal of Phenol from ....

\section{A] Optimisation of pH}

$\mathrm{pH}$ of the white radish peroxidase was optimised by measuring the activity of enzyme at $\mathrm{pH} 3,5,7$ and 9.

Table 6: Enzyme activity at different $\mathrm{pH}$ values

\begin{tabular}{|c|c|}
\hline $\mathbf{p H}$ & Enzyme Activity (units/l) \\
\hline 3 & 185 \\
\hline 5 & 200 \\
\hline 7 & 247 \\
\hline 9 & 225 \\
\hline
\end{tabular}

Thus, it was observed that the optimum $\mathrm{pH}$ of white radish peroxidase was 7 .

\section{B] Optimization of temperature}

The temperature of the white radish peroxidase was optimised by measuring the activity of enzyme at $25^{\circ} \mathrm{C}, 37$ ${ }^{\circ} \mathrm{C}$ and at $55^{\circ} \mathrm{C}$.

Table 7: Enzyme activity at different temperatures

\begin{tabular}{|c|c|}
\hline Temperature & Enzyme Activity(Units/L) \\
\hline $25^{\circ} \mathrm{C}$ & 245 \\
\hline $37^{\circ} \mathrm{C}$ & 200 \\
\hline $55^{\circ} \mathrm{C}$ & 175 \\
\hline
\end{tabular}

Thus, it was observed that the optimum temperature of white radish peroxidase was $25^{\circ} \mathrm{C}$.

\section{Immobilization of peroxidase enzyme extracted from white radish}

The white radish extract containing peroxidase showed the highest enzyme activity for efficient removal of phenol so it was immobilized by the entrapment method for reusability.

The enzyme was immobilized in the form of calcium alginate beads for phenol removal.

\section{A] Enzyme activity of the immobilized white radish peroxidase}

The enzyme activity of the immobilized enzyme was checked by using the Guaiacol assay in a similar way as it was performed for the free enzyme extract and the results obtained were as follows:

Table 8: Enzyme activity of immobilized peroxidase

\begin{tabular}{|c|c|}
\hline Natural Source & Enzyme Activity (Units/l) \\
\hline Radish & 245 \\
\hline
\end{tabular}

From the above result, it was observed that the immobilised enzyme had similar enzyme activity as compared to the free enzyme. The immobilised enzyme could be used repeatedly for the removal of phenol from industrial effluent.

\section{B] Phenol removal from industrial effluent by immobilized white radish peroxidase}

Table 9: Phenol removal by immobilized peroxidase.

\begin{tabular}{|c|c|}
\hline Phenol concentration in industrial effluent & O.D. at 510 $\mathbf{~ m}$ \\
\hline Initial & 4.000 \\
\hline Final [After Immobilized Enzyme Addition] & 0.147 \\
\hline
\end{tabular}

From the above result, it can be concluded that there was above $90 \%$ removal of phenol from industrial effluent was observed by using the immobilized white radish peroxidase. Thus, the activity of the immobilised peroxidase enzyme was found to be promising for effective phenol removal.

\section{Discussion}

Dec and J.M. Bollag (10) have demonstrated that plant materials like potato tubers, raw soybean hulls, turnip roots, onions and parts of fifty other plant species are effective carriers of peroxidase activity, which is instrumental in removing anilines and other aromatic compounds from water solutions. Bollag and co-workers studied the effectiveness of different enzymes like laccases, tyrosinases, peroxidases for waste water treatment. In this project the removal of phenol from industrial effluent was undertaken using enzyme peroxidase isolated from various natural sources and micro-organisms. Peroxidases catalyse the oxidation of phenols by hydrogen peroxide resulting in the formation of water insoluble polymers which can be separated by coagulation, sedimentation etc. The natural sources used were radish, broccoli, carrot, soybean and beetroot. The microorganisms used were Pseudomonas aeruginosa, Staphylococcus aureus and Bacillus subtilis. Firstly, the 
enzyme peroxidase was extracted from both the sources using ammonium sulphate fractionation technique. The measurement of peroxidase activity was undertaken by using the Guaiacol assay. The maximum peroxidase activity was exhibited by white radish enzyme extract.S. Chakraborty et .al (11) assessed the biodegradation of phenol by native organisms isolated from coke processing wastewater. In our study the micro-organisms used Pseudomonas aeruginosa, Staphylococcus aureus and Bacillus subtilis were assessed to study their potential of biodegradation of phenol. In this assay the ability of the organisms to utilise phenol as a sole carbon source was evaluated. The micro-organisms were grown on a mineral salt agar medium supplemented with phenol concentration of $200 \mathrm{mg} / \mathrm{l}$ at $25^{\circ} \mathrm{C}$ for $72 \mathrm{hrs}$. There was no growth seen on the mineral salt agar medium. The organisms could not use phenol as a sole carbon source. Wu. et al (1993) studied the effects of additives on aromatic compound removing capacity of enzymes. Phenol removal (phenol concentration measurement) assay was performed using white radish POD. The samples used in the phenol removal assay were:1] Industrial effluent 2] Synthetic phenol. For synthetic phenol, it was observed that with an increase in the enzyme dose, the removal of phenol increases. The initial phenol concentration was $4.5 \mathrm{mg} / \mathrm{l}$ and the final concentration reduced to $1.1 \mathrm{mg} / \mathrm{l}$. This shows that there was more than $90 \%$ removal of phenol. Decrease in the absorbance of phenol from industrial effluent over a period of 10, 20, 40,60 minutes was studied. In about 20 mins, phenol conversion higher than $90 \%$ was observed by the polymerisation reaction. Therefore, it was concluded that about $99 \%$ phenol from industrial effluent was removed by using the peroxidase enzyme obtained from white radish. When white radish peroxidase was added to synthetic phenol, formation of water insoluble phenolic polymers was seen. Cooper and Nicell (12) and Li, Tonegawa et al, (13) Stanisavljevic (2004) studied the effects of different parameters like enzyme concentration on the efficiency of phenol removal from solutions. Since maximum peroxidase activity and maximum phenol removal was shown by white radish enzyme extract optimisation of the $\mathrm{pH}$ and temperature of peroxidase from white radish extract was performed. $\mathrm{pH}$ of the white

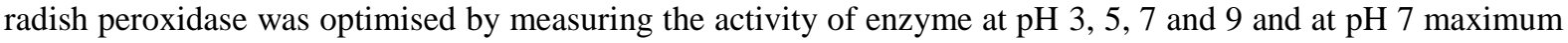
enzyme activity was seen. Therefore, the optimum $\mathrm{pH}$ of white radish peroxidase was found to be 7 . The temperature of the white radish peroxidase was optimised by measuring the activity of enzyme at $25^{\circ} \mathrm{C}, 37^{\circ} \mathrm{C}$ and at $55^{\circ} \mathrm{C}$. Since highest enzyme activity was observed at $25{ }^{\circ} \mathrm{C}$, the optimum temperature of white radish peroxidase was $25^{\circ} \mathrm{C}$. Syed Mustapha et al (2004) proposed an economical and high yield procedure for immobilization of peroxidases from turnip roots. The enzyme was immobilized in the form of calcium alginate beads for phenol removal. The enzyme activity of the immobilized enzyme was checked by using the Guaiacol assay in a similar way as it was performed for the free enzyme extract. It was observed that the immobilised enzyme had similar enzyme activity as compared to the free enzyme. The immobilised enzyme could be used repeatedly for the removal of phenol from industrial effluent. There was above $90 \%$ removal of phenol from industrial effluent using the immobilized white radish peroxidase. Thus, the activity of the immobilised peroxidase enzyme was found to be promising for effective phenol removal.

\section{Acknowledgement}

The authors wish to thank Department of Microbiology, Fergusson College, Pune for making the infrastructure available and Ms. Smruti Gore for helping us in the preparation of manuscript.

\section{References}

[1]. P.T. Vasudevan and L.O. Li, Peroxidase catalyzed polymerization of phenol, Appl.Biochem. Biotechnol,60,73-82, (1996)

[2]. Y.C. Lai, S.C. Lin, Application of horseradish peroxidase for removal p-chlorophenol from aqueous solution, Process Biochem,40,1167-1174, (2007)

[3]. K.Q. Wilberg, D.G. Nunes and J. Rubio. Removal of phenol by enzymatic oxidation and floatation. Braz J Chem Eng. vol $17 \mathrm{n} 4-7$ Dec 2000

[4]. Miodrag Stanisavljevic, Lidija Nedic. Removal of phenol from industrial waste water by horse radish peroxidase (Cochlearia armoracia L) FACTA UNIVERSITITATIS series: working and living environmental protection vol 2, No 4,2004, pp 345-349

[5]. Syed Mustapha, S. Akhtar, A.A. Khan and Q. Hussain, Simple and high yield procedure for stabilization of peroxidases from turnip roots, J.Science.Ind.Res., 63,540-547(2004)

[6]. A. Krastanov. Microbial degradation of phenol and phenolic derivatives., Engineering in Life sciences vol 13 issue 1 pp $76-87$ Jan 2013.

[7]. P.K. Churasia, S.K. Singh, S.L. Bharati Study of peroxidase obtained from Daucus carota(carrot) juice extract. Journal of Applicable Chemistry 2013,2(5): 1123-1131

[8]. J. Wu, K.E. Taylor et al Optimization of the reaction conditions for enzymatic removal of phenol from waste water in the presence of polyethylene glycol. Wat.Res. Vol 27 No.12 pp 1701-1706,1993

[9]. Khosravi Arezoo, Vossoughi Manouchehr Enzymatic removal of phenol and P-chlorophenol with horse radish peroxidase Nano dendrozyme

[10]. Bollag Jean Marc, DecJerzy, Oral presentation at symposium

[11]. S. Chakraborty, T. Bhattacharya, T.N. Patel and K.K. Tiwari, Biodegradation of phenol by native micro-organisms isolated from coke processing wastewater, Journal of environmental biology, 31,293-296, (2010)

[12]. V.A Cooper, J.A. Nicell Removal of phenol from foundry waste water using horse radish peroxidase. Wat Res.vol 30 No.4 April 1996 pp 954-964

[13]. M.Tonegawa, Jade. and J.M. Bollag, Use of additives to enhance the removal of phenols from water treated with horseradish and hydrogen peroxide, J. Environ.Qual,32,1222-1227, (2006) 